Itinéraires Itinéraires

Littérature, textes, cultures

2020-3 | 2021

Le rap, une poésie de performances

\title{
"Poetry whirlpool": Rhythm and Tangible Language in the Works of the Wu-Tang Clan and Booba
}

"Poetry whirlpool" : rythme et langage tangible dans les cuvres du Wu-Tang Clan et de Booba

\section{Léopold Reigner}

\section{OpenEdition}

\section{Journals}

\section{Electronic version}

URL: https://journals.openedition.org/itineraires/9089

DOI: 10.4000/itineraires.9089

ISSN: 2427-920X

Publisher

Pléiade

\section{Electronic reference}

Léopold Reigner, "'Poetry whirlpool": Rhythm and Tangible Language in the Works of the Wu-Tang

Clan and Booba", Itinéraires [Online], 2020-3 | 2021, Online since 08 December 2021, connection on 12 December 2021. URL: http://journals.openedition.org/itineraires/9089 ; DOI: https://doi.org/10.4000/ itineraires.9089

This text was automatically generated on 12 December 2021.

\section{(c) (†) $\odot$}

Itinéraires est mis à disposition selon les termes de la licence Creative Commons Attribution - Pas d'Utilisation Commerciale - Pas de Modification 4.0 International. 


\section{"Poetry whirlpool": Rhythm and Tangible Language in the Works of the Wu-Tang Clan and Booba}

"Poetry whirlpool" : rythme et langage tangible dans les cuvres du Wu-Tang Clan et de Booba

Léopold Reigner

1 In the introduction to Global Linguistic Flows, H. Samy Alim details the habitual distinction made by performers between rap and Hip Hop:

Although the terms rap and Hip Hop are sometimes used interchangeably, Hip Hop is used by practitioners to refer to a vast array of cultural practices including MCing (rappin), DJing (spinnin), writing (graffiti art), breakdancing (and other forms of streetdance), and cultural domains such as fashion, language, style, knowledge, and politics, all of which give us "Hip Hop culture." "Rap" then, or "rappin," is constructed as one practice within "the whole culture of the movement," as U.S. Hip Hop pioneer Afrika Bambaataa would put it. (Alim 2009: 2)

MCing is often paired with DJing, which provides a musical foundation to the MC's delivery. What sets rapping apart, however, is its relationship with language: "Given the dominance of rapping in Hip Hop cultural practice, language is perhaps one of the most useful means by which to read Hip Hop culture" (Alim 2009: 5). Analysis of the linguistic element of Hip Hop may therefore rely on studies of rapping and the lyrical output of Hip Hop artists.

3 This, however, does not readily legitimize a literary analysis based on close reading of rap lyrics. Even though there are a cappella releases of Hip Hop albums, ${ }^{1}$ most Hip Hop songs are made up of language as well as music. It may seem that, unlike the literary genre of poetry, writing in Hip Hop is merely one part of a larger musical composition. Yet, words are of paramount importance for rappers and beat making is more often than not taken care of by another artist, whose skill is only musical and not literary. The literary aspect of Hip Hop is therefore extremely strong, represented in the MCing practice. This raises the question of the importance of the delivery of the text in the 
performance, and whether this allows for a literary analysis, through close readings, of the text itself. Indeed, it may be argued that orality is inherent to the work of art, and that analyzing rap lyrics only as a written text is bound to generate an incomplete study. A counterpoint may be found in the example of theatrical plays, which are likewise written in order to be performed on stage, without this primary intent constituting an obstacle to literary analysis.

of course, poetry is the literary genre that has most often been compared to rap, the strongest argument being the presence of rhyming patterns and the syntactic litheness of the text due to the importance of sound and rhythm. For example, where some poets are forced to find a word with a certain number of syllables to fit into a particular line in order to preserve its structure, so are rappers faced with what Martin Connor calls "the rhyme barrier":

The rhyme barrier is the natural limiting of word choice for a rapper when they decide to choose a word. At the start of a rap, the rapper can choose any words to say. But once he decides to rhyme those words, his word choice is then restricted to only words that rhyme. How well a rapper negotiates the rhyme barrier is, for me, a measure of how good a rapper is. Can they continue to stay on topic, while still dropping complex rhymes? (Connor 2013)

The two genres are not entirely similar, again because of the musical element, as Chuck D notes in a 1999 interview published in That's the Joint: "Poetry makes the beat come to it, and Rap pretty much is subservient to the beat [...] I think where you have the beginning of the meshing of the two (Rap and poetry) began with KRS-One, where they actually slowed the beat down to themselves." (Alim 2004: 551) Even though rappers do not need to stay on beat, the fact that the delivery of the lyrics is performed along with the beat means the two are very closely linked.

Still, what connects rap to poetry is not only the structure of the lyrics, but the fact that rapping can be compared to public readings of poetry. Such readings have become more and more common. Without condemning them, Jan Baetens in his 2016 book $\grave{A}$ voix haute, details the tension between the written word and the spoken word: "Nowadays, a writer has no choice. Either he is willing to read his texts aloud to an audience or he is doomed to be forgotten. Without speech, the text-particularly poetry -can only disappear"2 (Baetens 2016: 5). Despite the fact that in rap the word is systematically spoken, poetry brings forth the same issues of orality and rhythm:

The reality is that the poem, although printed on the page, has always been spoken, delivered through speech, by word of mouth. Guillaume Apollinaire, who is believed to have said his poems aloud before writing them down, envisioned a phonographic future for poetry, freed from the printed page. (Pardo, Lang and Murat 2020:9)

7 This quote is taken from the introduction to Archives sonores de la poésie, which aims to study performed poetry, in its spoken form, by notably borrowing Charles Bernstein's notion of "close listening" put forth in his 1998 collection of essays Close Listening: Poetry and the Performed Word. In it, Bernstein details the necessity of including orality in a study of poetry and offers a new method of analysis:

Close listenings may contradict 'readings' of poems that are based exclusively on the printed text and that ignore the poet's own performances, the 'total' sound of the work, and the relation of sound to semantics [...] Any account of poetry readings must also give an account of the sound of poetry. (Bernstein 1998: 4)

Such a notion may be applied to rap: an analysis based on "close listening" could focus on the stylistic aspects of both rap lyrics as a text and the delivery of such lyrics. 
This raises a final obstacle to the analysis of rap through "close listening," which is the issue of transcripts. When CDs were the norm, lyrics were sometimes available as text in booklets inserted in the case. Whether the authors themselves provided the text or guaranteed its accuracy is difficult to ascertain. Some rappers, like Jay-Z, claim to never write down a word, making their rap a purely spoken word, although the fixed nature of recordings allows listeners to create their own transcripts. Websites such as Genius.com host such open collaboration transcriptions, which allow for a great number of songs to be available in textual form. These are the transcripts used in this paper, but this implies that such texts are used only for the purpose of analysis and written quotations, with the consideration that rap remains an essentially spoken form. Without having been verified by the artists themselves, they remain transcriptions, not fully fledged authorial productions, and close listening evidently has to rely on the authors' delivery of the songs themselves: "[...] the transcription of a speech is never the visual copy of a spoken production, for the usual notation systems omit a number of essential parameters such as intonation, stress, speed, the type of voice and so on" ${ }^{4}$ (Baetens 2016: 10).

9 The songs of the Wu-Tang Clan may provide an interesting example to analyze by using a close listening perspective. In the song "For Heaven's Sake," rapper Cappadonna uses the term "poetry whirlpool" to describe the creative relationship between two artists, RZA and True Master, which indicates a professed link between rap and poetry, ${ }^{5}$ and also associates it to an original perspective on the conflict trope often found in rap, which is here described as a source of creativity through the metaphor of conflicting currents that draw poetry in. Wu-Tang Clan songs are made up of several verses and each verse is written by a different member, so that all the artists have only one verse to express themselves and a song is made up of a collection of writing styles delivered in different flows. In this way, the Wu-Tang Clan's work is related to battle rap, a genre where wit constitutes the ultimate benchmark and works are all but judged on this criterion alone. Moreover, the Wu-Tang Clan, as a group, contains multitudes of different styles and approaches to writing which match different rap genres. Indeed, in the same song, one member may indulge in storytelling rap, using the past tense to describe a fictional situation, while another may partake in "conscious" or political Hip Hop, and yet another member may engage in gangsta rap. This diversity of styles makes the group an ideal subject for examination. The group's music also spans from the early days of the mainstream breakthrough of Hip Hop music, the nineties, up until today.

In order to increase the diversity of the works analyzed in this paper, it may be useful to include a non-US based rapper. Indeed, the ambivalent relationship between global Hip Hop and US Hip Hop means that the former provides an interesting contrast to the latter:

A growing body of research on Hip Hop outside the United States documents how its various local articulations depart from the "original" in significant ways-in rap music, for example, in terms of language choice, song topics, cultural reference and sampling practices [...] However, even though local Hip Hop acquires features and invites interpretations that no longer rely exclusively on its African American origins, it does not lose its global imprint, but rather evolves in a constant dialogue with its 'mother culture,' by drawing on U.S. Hip Hop as a source for new trends and as a frame for the interpretation of local production. The persistent dialogue between the global and the local is manifested in both discourse and in language style. (Androutsopoulos 2009: 43) 
11 Booba is a French Hip Hop artist who also has a lot of notoriety. Both Booba and the Wu-Tang Clan would belong to what Jannis Androutsopoulos calls the "primary sphere" of Hip Hop which "encompasses all productions which originate [...] in a particular country" (Androutsopoulos 2009: 46) and are given a great amount of attention by audiences. Booba also demonstrates an ebb and flow approach to the Wu-Tang Clan as a predecessor (Booba's first release as a member of the group Lunatic came out seven years after Wu-Tang's 1993 debut album). Indeed, Booba recently paid homage to the group in the song "Zer" from his 2015 album Nero Nemesis, whose chorus consists entirely of the name of the US group being repeated several times. However, he has also used the group as an example of an outdated style of rapping in an interview of the same year:

Many rappers today refuse to evolve, they remain trapped in the same musical style and are still seeking their flow by listening to the Wu-Tang. They don't understand that Wu-Tang is outdated now. It's as if I was looking for the same kind of instrumentals Mobb Deep used when I was coming out with my first album. ${ }^{6}$ (Doucet and Fall 2015)

This raises the question of influence in Hip Hop as well as the authors' vision of the artform. Moreover, both the Wu-Tang Clan and Booba's works can benefit from an analysis which nuances their categorization as gangsta rap or thug rappers. While it is clear that this genre is deeply entrenched in their respective work, evidenced by their consistent use of the lyrical warfare trope-using metaphors to link words with weapons-there is a more complex approach to it, linked to the question of materialization of language. In Michael Newman's chapter “That's All Concept: It's Nothing Real" in Global Linguistic Flows, he mentions the oversimplification of such categorization regarding the Wu-Tang Clan:

A clear example of normatively transparent interpretations involved thug rap, a term the MCs used for rhymed autobiographical recounting of violent or criminal life. This definition is implicit in another MC, Kaliph's, effort to correct my misclassification of $\mathrm{Wu}$-Tang Clan as thug rappers. Although Wu-Tang spit images of violent criminality, and members are known for having participated in such activities, Kaliph believes their violent images were really opaque. (Newman 2009: 198)

Booba's rap, likewise, has often been classified as thug rap due to the themes found in his songs. However, he has also been praised for the diversity of his images beyond this thematic frame as well as for putting forth an original, inverted vision of the common lyrical warfare metaphor.

Lyrical warfare as a general theme is to be found throughout the works of the Wu-Tang Clan. Not only do the members refer to themselves as "generals" but the theme permeates their verses. An example of this may be found in Ghostface Killah's verse from the song "Protect Ya Neck":

Ejecting styles from my lethal weapon

My pen that rocks from here to Oregon

Here's Mordigan, catch it like a psycho flashback

I love gats, if rap was a gun you wouldn't bust back

The pen, the instrument of word composition, is described as a lethal weapon. The slang word "gats" avoids the repetition of "guns" and creates an assonance with the [a] sound. Finally, rap is directly compared to a weapon in a hypothetical construction, with the artist arguing that his mastery of language is such that if words could truly kill, his adversary, referred to as "you," would perish. Beyond this metaphor, however, 
the mention of the pen and its substitution for the author's rap, which is of course what is travelling "from here to Oregon," not only puts the emphasis on the linguistic aspect of Hip Hop but also constitutes a metonymic device that concretizes the apparently immaterial notion of the spoken word.

Ghostface Killah's delivery of these lines further demonstrates the difficulty posed by transcripts. The transcript in this case seems to follow the structure of bars as a grouping together of four beats. For example, in the second line, Ghostface Killah stresses four syllables: "pen," "rocks," "here," and the first syllable of "Oregon." Yet, this does not account for the pause clearly taken after "pen," which puts great emphasis on this word and brings attention to the metonymy. While a comma could indicate the break and the consequent syntactic oddity may be dismissed as poetic license, the issue of using line breaks at the end of each bar is also manifest in the fact that it hints at a sonic pause and can create an enjambment effect. Ghostface Killah, however, does not break between the third and fourth bar and only pauses after "I love gats," contrary to the syntactic and typographic hints of the transcript. The jarring effect of this fluid delivery, creating an apparent non-sequitur with the words "I love gats," is lost in the textual form. Perhaps a transcript using line breaks to denote pauses would better illustrate the rhythm of oral delivery:

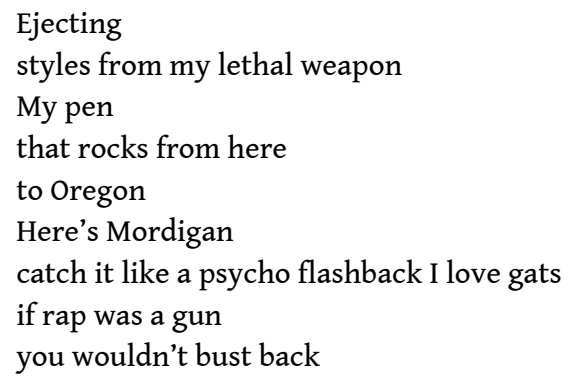

Likewise, in the song "For Heaven's sake," Inspectah Deck evokes weapons of war to characterize language, but this is coupled with other metaphors linking concrete and material objects with the rapper's language:

My grenades raid the airwaves, catch this rap page

I glide like, hovercrafts on the Everglades

Boom master, with the faster blade, tracks slasher

Manufacture poems to microphones, bones fracture

"Grenades" and "blades" which cause "bones" to "facture" are one warfare metaphor used to describe the rapper's poetry but his delivery is then compared to a Florida hovercraft to highlight its speed and fluidity. A very vivid image makes an abstract skill concrete, and the listener is even encouraged, through the use of the imperative, to "catch this rap page." In these lines, language is materialized to an extent where the spoken word can be grabbed and experienced in a tactile manner. If we consider the syntax, there is another unexpected pause after "I glide like," indicated in this transcript by a comma, not a line break. However, commas create syntactic units, and the effect here seems closer to an enjambment, with a delayed meaning creating tension as the listener awaits the reveal of the comparison.

This Inspectah Deck verse from the song "Triumph" showcases a similar situation:

I bomb atomically Socrates' philosophies

And hypothesis can't define how I be dropping these mockeries

Lyrically performed armed robbery 
The three lines form a whole sentence, and are separated in terms of syntactic breaks, the first one before the conjunction and the second before the last object. However, listening to the delivery by Inspectah Deck, there are critical pauses after "atomically," "hypothesis" and "performed." This shows the challenge posed by rap to poetic typography, since it should be determined whether to use a line break according to syntactic logic, line length or the author's delivery. Here, the choice of line length obfuscates the fragmented rhythm which allows Inspectah Deck to deliver each piece of the sentence as if they were lines themselves, putting more stress on words and overwhelming the listener with strong syntactic units created through his delivery. This line by ODB from "Protect Ya Neck" displays a similar issue with typography and oral delivery: "Come to my center, you enter the winter." If one were to read this line aloud, the only break would be the comma that seemingly separates the bar in two pairs of beats. And yet, in the song it is clear ODB makes strong pauses after "Come to" and "you enter," creating a binary rhythm with four two-syllables fragments. Of course, using line breaks would make little syntactic sense:

Come to

My center

You enter

The winter

However, it would portray much more accurately the rhythm of the delivery. Roland Barthes reflects on the line break when he discusses the haiku in La Préparation $d u$ roman:

Typography, I think, conditions the reading; the fact that we have a hard return after each line in the tercet is very important, because this constitutes the haiku [...] We may say that when we follow a line break after a line and that we therefore leave a blank space, this blank space is like a kind of air, a buffer of air, a wall of emptiness, a wall of air, and that is what makes a line. (Barthes 2015: 68-69)

In rap music, the text is heard, rarely read, so that the "buffer of air" exists through the rapper's delivery.

This is also seen in Booba's writing, for example in the song "Pitbull”: “J'en suis où j'en suis, malgré tellement d'erreurs/J'suis trop en avance pour leur demander l'heure."

Again, Booba's performance when delivering the text makes it clear there are pauses after "J' suis" and "leur." These are similar to enjambments, creating a demand from the listener who wishes to hear the rest of the line since the pause is clearly both a rhythmical and semantical interruption. The effect of this is the heightening of the payoff provided by the abrupt end of the sentence. A transcription taking these pauses into account would look like this:

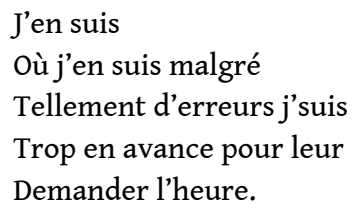

In "Bâtiment C," Booba delivers this line : "Pour m'arrêter faudra m'enl'ver la vie." ${ }^{10}$ Listening to the performance, there is a pause after "faudra," creating two fragments of two beats each but the rejet contains fewer syllables (four with the contraction of "enlever") and is therefore all the more striking.

In "Couleur Ebène," ${ }^{11}$ Booba uses a three-second pause to achieve the effect of an abrupt and surprising ending which contrasts with the preceding line: 
Si t'as pas

D'raisons de vivre

Trouve une raison de crever $^{12}$

There is a pause in the delivery after "pas," and an exceptionally long, dramatic pause before the second line, which is delivered as a strong authoritative statement without any pauses.

In Booba's work, as in Wu-Tang Clan songs, language is often associated to material objects, with the lyrical warfare metaphor as a starting point. In "Trône," Booba even compares his language to a weapon: “T'es témoin d'un mariage entre une Kalash et une plume." ${ }^{13}$ The metaphorical marriage highlights the addition of the combat element to language, but first uses metonymy to describe language as material. The image of the quill is a recurring one in Booba's lyrics and is found in the title of his 2002 song "Le bitume avec une plume," ${ }^{14}$ which associates two metonymies to concretize language. The rhyme reinforces this effect and Booba ends the song by repeating the words "bitume, plume" ten times in a row, blurring the lines between language and physicality. In the song "Pitbull," Booba, much like Ghostface Killah comparing rap to a gun in "Protect Ya Neck," uses a metaphor which connects poetry lines and spears: "Mes rimes te touchent au cœur en plein sternum." ${ }^{15}$ Whether this is strictly a combat reference or a continuation of the quill metaphor-the pen or the sword striking the heart as either a destructive or a creative force-this further demonstrates the complexity and ambiguity of the link between conflict and creativity. In the song "Mové Lang," Booba also reverses the axiom "le savoir est une arme" which links intellectual ability to physical strength: "Le savoir est une arme / trois calibres sur moi je suis très intelligent." 16 By reversing the causality link in the chiastic phrasing of the axiom, Booba sheds light on its absurdity and presents a novel approach to the lyrical warfare trope.

Furthermore, Booba sometimes personifies his language, portraying it as a body in a state of constant physical improvement: “Mon rap prend de la protéine, soulève v'la les haltères"17 ("Le Duc de Boulogne"). Raekwon has a line with a similar theme in "Protect Ya Neck": "Rhymes rugged and built like Schwarzenegger." In Booba's case, the device may be hypallage, but in both cases language is described as a physical composition, which, like a human body, can be sharpened and strengthened through exercise and practice. This shows a vision of rapping as a meticulous and painstaking process of rewriting until the perfect, condensed, "rugged" text can be found. In "It's Yourz", Inspectah Deck likens rhyme to a drug, which echoes the idea of the text as something to be refined for the reader/listener's appreciation: "I crystallize the rhyme so you can sniff it." The theme of materialization, in this case crystallization, is still present: rapping is a process of refining language in order to create a tangible work that can be experienced in three dimensions.

In "For Heaven's Sake," Masta Killa depicts writing as a way to elevate the mind of the writer who is capable of creating a rich and abundant composition:

[...] just respect my prolific pen

As I ascend, the minds of the weak

To rise and take power Eiffel tower-ing over the land

The use of "Eiffel tower" as a verb showcases the rapper's creative use of language, while pointing to the self-referential use of rapping in a materializing metaphor. Words can even perform miracles, as in Masta Killa's verse in "Triumph": 
As we engage in battle the crowd now screams in rage

The high chief Jamel Irief takes the stage

Light is provided through sparks of energy

From the mind that travels in rhyme form

Giving sight to the blind

The war metaphor is still present, even engaging the listener or reader into the fight, but in the third and fourth lines words are described as energy, which takes a linguistic form but is capable of "giving sight to the blind," giving materiality to the text.

If the way a physical body becomes stronger and sharper is through exercise, a verse becomes pithy through composition and delivery. One of the consequences of the addition of sound to the linguistic experience is that some devices, such as rhymes or alliterations and assonances, take on an additional dimension.

In this verse from Inspectah Deck in "C.RE.A.M." we find an alternate rhyme scheme, as well as internal rhymes:

Leave it up to me while I be livin' proof

To kick the truth to the young black youth

But shorty's runnin' wild, smokin' sess, drinkin' beer

And ain't tryin' to hear what I'm kickin' in his ear

Neglected for now, but yo, it gots to be accepted

That what? That life is hectic

There is an alternate and internal / $u: \theta /$ rhyme in the first two lines, a recurring internal /In/ rhyme in the first, third and fourth lines, an alternate /Iər/ rhyme in the third and fourth line and lastly a both internal and final rhyme in /lk/ in the last three lines, culminating in the word "hectic" which contains the sound twice. When reading this, one's inner ear notices the rhymes. But when listening to Inspectah Deck's delivery, the stress the rapper puts on the rhyming syllables, particularly the $/ \mathrm{u}: \theta /$ and /Iər/ sounds, reinforces the scheme to the point where it frames the verse almost entirely. In this verse from U-God in "It's Yourz," the /u:m/ rime is ubiquitous:

It's a quarter full moon, I arrive, women swoon

Well groomed, dance hall packed, full room

Lady move, peep my glide, peep my zoom

Keep in stride, smoke the la, smoke the boom

Feel the fumes, consume toxic tunes

Although the eye rhyme in -oom is only a feature of the written text, this does not replace the stress given to each of these sounds during the delivery.

We also find alliterations in [w] in the first line, and in [t] and [f] in the last line. These are likely to be perceived by readers, but on occasion alliterations are used so much that some lines all but become tongue twisters, such as this line from U-God in "Triumph": "I sing a song from Sing-Sing sipping on ginseng." In these two lines by Inspectah Deck in "Da Mystery of Chessboxin," the internal rhyme with the diphthong /aIər/ is paired with a double alliteration in /dr/: "Well I'm a sire, I set the microphone on fire/With the drunk driver driving, there's no surviving." In these cases, the performer puts the focus on these devices by stressing the relevant syllables and adds to the sensory experience.

Booba also uses repetitions of sounds such as alliterations and rhymes, for example in this line from the song "Trône," where Booba also uses multilingualism: "J'crache fumée épaisse de White Widow vers la window." ${ }^{18}$ In "Comme une étoile," 19 one line contains multiple occurrences of the /ов/ rhyme : "Le piano m'endort, Terminator est mon mentor, récupérer mon or j'en rêve encore.” ${ }^{20}$ 
Tone is a crucial factor in the way oral delivery and performance affects the text. In this Inspectah Deck verse from "Protect Ya Neck," the change in speed and volume makes a considerable difference in rhythm:

I smoke on the mic like smoking Joe Frazier

The hell raiser, raising hell with the flavor

Terrorize the jam like troops in Pakistan

Swinging through your town like your neighborhood Spiderman

So uhh, tic toc and keep ticking

While I get you flipping off the shit I'm kicking

The Lone Ranger, code red, danger!

The alliterations in $[\mathrm{r}],[\mathrm{f}],[\mathrm{s}]$ and $[\mathrm{t}]$ are immediately noticeable, but a change in tone in the third and fourth line is invisible with only the written text at hand. Only by listening to the song can one realize the true power of the fourth line, which acts as a climax for the verse, a peak towards which Inspectah Deck climbs and from which he goes down in the rest of the verse. Indeed, while he uses a loud, for the first two lines, volume and slow speed, creating an authoritative tone, for the first two lines, using many pauses (after "mic," "raiser") he accelerates for the third line and performs the fourth with no pauses whatsoever and a louder voice and fast-paced rhythm, creating a passionate tone. The longer line is delivered as fast as the others, and the absence of pauses and rising rhythm on the final word "spiderman" produces a fluid line contrasting with the halting rhythm of the rest of the verse, notably evidenced by the insertion of a filler word, "uhh," in the next line. This rhythm, which carries part of the meaning of the verse, cannot be seen in a close reading of the transcript and requires close listening.

"The academic enterprise employs various methodologies and theoretical approaches in the exploration of Hip-Hop's cultural expressions, illuminating emergent phenomena and explaining the latent potentials among Hip-Hop's various cultural forms" (Forman 2004: 1). The multifarious nature of the object of study calls for a diversity of approaches. When discussing the aspect of language in Hip Hop and analyzing rap lyrics, however, the importance of oral delivery can hardly be ignored, lest the rhythm of the text be lost since it hinges heavily on the performer's choice of delivery. Transcriptions which follow the structure of versification, the length of sentences and syntactic units without taking into account the author's performance risk losing essential meaning found in stresses, speed, and breaks. The notion of close listening, as well as the similarities of rap to poetry, bolster the possibility of a literary analysis of Hip Hop lyrics, and the perspective of rap as, among other artistic expressions, a literary genre. Ideally, an analysis of language in rap could perhaps bridge literary theory, close listening and musicology. The lyrics of the Wu-Tang Clan and Booba contain multitudes of poetic and rhythmic devices which may be seen in written form and heard by listening to the artists' delivery. Moreover, the study of these oral texts shows a specific vision of rap as an art which can create a tangible form of language. These lines by U-God from "Da Mystery of Chessboxin" are further proof of this: "My Hip Hop will rock and shock the nation/Like the Emancipation Proclamation." U-God compares his language to a truly performative document, Lincoln's Emancipation Proclamation, so that rap is not only a literature of performance but also a literature of performative language. 


\section{BIBLIOGRAPHY}

Alim, Samy H., Ibrahim, Awad, and Pennycook, Alastair (eds), 2009, Global Linguistic Flows, New York, Routledge.

Alim, Samy H., 2004, “'Bring It to the Cypher': Hip Hop Nation Language," in M. Forman and M. A. Neal (eds), That's the Joint, New York, Routledge, p. 530-63.

Androutsopoulos, Jannis, 2009, "Language and the Three Spheres of Hip Hop," in S. H. Alim, A. Ibrahim, and A. Pennycook (eds), Global Linguistic Flows, New York, Routledge, p. 43-62. Baetens, Jan, 2016, À voix haute, Bruxelles Les Impressions Nouvelles.

Barthes, Roland, [2004] 2015, La préparation du roman, Paris, Seuil.

Bernstein, Charles (ed), 1998, Close Listening: Poetry and the Performed Word, Oxford, Oxford UP.

Connor, Martin, 2013, “Rapper's Flow Encyclopedia - MF DOOM Analysis," RapAnalysis.com, 1 July 2021, [Online], https://www.rapanalysis.com/2013/05/rappers-flow-encyclopedia-mf-doo/, accessed June 102021.

Doucet, David and Fall, Azzedine, 2015, "Booba : l'interview vérité sur toute sa carrière," Les Inrockuptibles, 17 March 2021, [Online], https://www.lesinrocks.com/musique/booba-interviewverite-sur-toute-sa-carriere-144679-15-03-2015/, accessed 2 June 2021.

Forman, Murray and Neal, Mark Anthony (eds), 2004, That's the Joint, New York, Routledge.

Lang, Abigail, Murat, Michel, and Pardo, Céline (eds), 2020, Archives sonores de la poésie, Dijon, Les Presses du réel.

Newman, Michael, 2009, “'That's All Concept; It's Nothing Real': Reality and Lyrical Meaning in Rap," in S. H. Alim, A. Ibrahim, and A. Pennycook (eds), Global Linguistic Flows, New York, Routledge, p. 195-212.

\section{Corpus}

Booba, 2004, "Bâtiment C," Panthéon, Meudon, Tallac Records.

Booba, 2006, "Pitbull," Ouest Side, Meudon, Tallac Records.

Booba, 2006, “Couleur ébène," Ouest Side, Meudon, Tallac Records.

Booba, 2006, "Boulbi," Ouest Side, Meudon, Tallac Records.

Booba, 2010, “Comme une étoile," Lunatic, Meudon, Tallac Records.

Booba, 2015, “Zer," Nero Nemesis, Meudon, Tallac Records.

Booba, 2015, “Mové Lang,” D.U.C., Meudon, Tallac Records.

Booba, 2015, “Les Meilleurs," D.U.C., Meudon, Tallac Records.

Booba, 2017, “Trône," Trône, Meudon, Tallac Records.

Wu-Tang Clan, 1993, “C.R.E.A.M.," in Enter the Wu-Tang (36 Chambers), New York, Loud/RCA Records. 
Wu-Tang Clan, 1993, "Da Mystery of Chessboxin," in Enter the Wu-Tang (36 Chambers), New York, Loud/RCA Records.

Wu-Tang Clan, 1993, "Protect Ya Neck," in Enter the Wu-Tang (36 Chambers), New York, Loud/RCA Records.

Wu-Tang Clan, 1997, “A Better Tomorrow,” Wu-Tang Forever, New York, Loud/RCA Records.

Wu-Tang Clan, 1997, “For Heaven's Sake,” Wu-Tang Forever, New York, Loud/RCA Records.

Wu-Tang Clan, 1997, “It's Yourz," Wu-Tang Forever, New York, Loud/RCA Records.

Wu-Tang Clan, 1997, “Triumph,” Wu-Tang Forever, New York, Loud/RCA Records.

\section{NOTES}

1. Jay $\mathrm{Z}$ notably released an instrumental-free version of his album American Gangster in 2007, a release which put all the emphasis on the delivery of the written text, the lyrical element coupled with orality.

2. “L'écrivain, aujourd'hui, n'a plus le choix. Ou bien il accepte de lire ses textes en public ou bien il se condamne à l'inexistence. Sans la parole, le texte - surtout le texte poétique - ne peut que disparaître." All quotes from the article are translated by the author.

3. “C'est que le poème, malgré son inscription sur la page, n'a jamais cessé d'être dit, véhiculé oralement, de bouche à oreille. Guillaume Apollinaire, qui dit-on parlait ses poèmes avant de les fixer par écrit, imaginait pour sa part un avenir phonographique à la poésie, dégagée de la page imprimée."

4. “La transcription d'un énoncé oral n'est jamais le double visuel d'une production vocale, car les systèmes de notation habituels omettent un certain nombre de paramètres essentiels comme l'intonation, l'accent, la vitesse, le type de voix et ainsi de suite."

5. "Poetry whirlpool, Rza and True collide."

6. "Beaucoup de rappeurs refusent l'évolution, s'enferment dans le même registre musical et cherchent encore leur flow en écoutant du Wu Tang. Ils n'ont pas compris que Wu Tang, c'est pété aujourd'hui. C'est comme si je cherchais mes prods dans le même délire que l'époque Mobb Deep de mon premier album."

7. "Donc la typographie est, je crois, une détermination de lecture ; le fait qu'on aille à la ligne après chacun des vers du tercet est très important, car cela constitue le haïku [...] On peut dire que quand on va à la ligne après un vers et qu'on laisse par conséquent un blanc, ce blanc est comme une sorte d'air, un tampon d'air, une cloison de vide, une cloison d'air, et que c'est cela qui fait le vers."

8. "I am where I am despite so many mistakes/I'm too far ahead to ask them what time it is."

9. "Building C."

10. "To stop me taking my life will be a necessity."

11. "Ebony color."

12. "If you don't have a reason to live/Find a reason to die." 
13. "You are witnessing a marriage between a Kalashnikov and a quill."

14. "Concrete with a quill."

15. "My rimes strike your heart straight through the breastbone."

16. "Knowledge is a weapon/Three guns on me I'm highly intelligent."

17. "My rap takes proteins lifts a lot of weights."

18. "I blow thick (sic) smoke of White Widow through the window."

19. "Like a star."

20. "The piano puts me to sleep, Terminator is my mentor, I still dream about getting my gold back."

\section{ABSTRACTS}

Rap is an art form centered around language. As such, it may be studied using a language-focused methodology. However, in the case of rap, the delivery is almost always performed by the artist themselves, so that rap is always performed literature, and an analysis should take this performance into account. This raises the issue of the validity of performing close readings on works which exist primarily in oral rather than in written form. Studies of orality and public readings of poetry have put forth the notion of close listening, which unlike close reading encompasses the analysis of the oral delivery of a written text. A study of rap based on close listening, examining transcripts while taking the delivery into account, may prove revealing as to the changes in meaning involved in the performance. The lyrics and performances of a rap group, the Wu-Tang Clan, containing a diversity of styles, even genres, along with a non-US based solo rapper, Booba, separated by time, geography and style but linked by a common uncompromising misclassification in the thug rap genre as well as a complex approach to the lyrical warfare trope, could constitute diversified objects of study leading to general observations on these artists and their works.

Le rap est une forme d'expression artistique fondée sur un usage de la langue. En tant que telle, il est possible de l'étudier en déployant une méthodologie également centrée autour du langage. Cependant, dans le cas du rap, la performance orale est presque toujours effectuée par les artistes eux-mêmes, de sorte que le rap est toujours une littérature de performance, et toute analyse devrait prendre cet aspect en compte. Cela soulève la question de la validité des micro-analyses textuelles en ce qui concerne des œuvres existant d'abord oralement plutôt qu'à l'écrit. Les études de l'oralité et des lectures publiques de poésie ont apporté la notion de "close listening " qui, contrairement à la micro-analyse textuelle, prend en compte l'analyse de la performance orale. Une étude du rap fondée sur le « close listening », en utilisant les transcriptions pour citer le langage tout en se concentrant sur la performance orale, pourrait mettre au jour les différences entre le texte à l'écrit et les modifications de sens engendrées par l'écoute. Les paroles et les performances du groupe de rap Wu-Tang Clan, qui contient une diversité de styles, même de genres, ainsi que celles d'un rappeur solo non états-unien, Booba, séparés par le temps, la géographie, et le style mais liés par une catégorisation trop peu flexible dans le genre du thug rap ainsi que par une approche complexe du topos de la guerre des mots, pourraient constituer des objets d'étude variés menant à des observations générales sur ces artistes et leurs œuvres. 
INDEX

Keywords: hip hop, Booba, Wu-Tang Clan, literature, close listening, style, poetry Mots-clés: hip-hop, Booba, Wu-Tang Clan, littérature, close listening, style, poésie

\section{AUTHOR}

\section{LÉOPOLD REIGNER}

Université de Rouen, Laboratoire ERIAC 